\title{
EVALUATION OF CRUDE OILS AND NATURAL GASES OF KURDISTAN-IRAQ BY CATALYTIC IMPROVEMENTS TO LIGHTER OILS USING LOCAL CLAYS
}

\author{
SALAHALDIN NAMAN, LAZGIN A. JAMIL, FIRAS AL-GULAMI, SHERWAN SIMO \& MAHER K. ALI \\ Department of Chemistry, Faculty of Science, University of Zakho, Iraq
}

\begin{abstract}
The chemical and physical properties of three different crude oils and two natural gas wells in Kurdistan-Iraq have been studied according to American Standard Test Method (ASTM) methods. Auto-distillations have been used to determine the changes in each cut, and gas-liquid chromatography has been used to find the approximate chemical constituents. A distribution diagram of paraffin, naphthenic, and aromatic hydrocarbons has been created. The gasoline cuts for each crude oil have been examined to find suitable octane additives (oxygenated or metal organic). The octane number increases as a function of the amount of additives, which has been plotted. A correlation between the trace metals and the types of hydrocarbons has been carried out for each crude oil. The improvement of these crude oils is achieved catalytically by reactions at high temperatures using different local clays, which gave us increases in lighter molecules by $7 \%$ (max). Chemical reactions are suggested for this improvement. $\mathrm{X}$-ray analysis is also performed for each clay. Research is carried out on one gas-liquid well (Khor Mor) and another pure natural gas well. Gas chromatography analysis for Khor Mor shows 51\% C1C5 and 49\% C6-C11, while other natural gas wells contain 98\% methane. The natural gas of the Kirkuk wells contained approximately $10-12 \%$ hydrogen sulfide, which we separated using ethanolamines, and converted to hydrogen fuel and sulfur at two pilot plants using a new catalyst instead of the previous Clause process, producing about 143 tons of hydrogen per day.

Keywords: crude oil, natural gas, evaluation, hydrogen sulfide, Kurdistan.
\end{abstract}

\section{INTRODUCTION}

Crude oil is a mixture of gaseous, liquid, and solid hydrocarbon compounds, and also contains small quantities of nitrogen, oxygen, and sulfur-containing compounds as well as trace amounts of metallic constituents [1]. Crude oil is usually evaluated through various physical and chemical methods. Crude oil has been known about for a long time. Archeologists have shown that it had already been extracted and used for about 5-6 thousand years BC Petroleum has also been known about for a long time. The first use of petroleum was at the Tigris-Euphrates valley, Iraq, which was inhabited as early as $4000 \mathrm{BC}$ by a people known as the Sumerians who established one of the first great cultures of the civilized world [2]. Petroleum is one of the most important substances consumed by man at the present time.

Petroleum is used as a principal source of energy for industry, heating, and transportation, and it also provides the raw materials for the petrochemical plants to produce polymer, plastics, and many other products. It has also been used in very primitive ways, especially in transportation and heating, which now represent as the main source of polluted gases on the planet.

There are several theories on the formation of petroleum, which is a complex mixture of hydrocarbons in sedimentary rocks in the form of gases (natural gas), liquids (crude oil), semisolids (bitumen), or solids (wax or asphaltene) [3], [4].

In this paper, we aim to evaluate and improve the constituents of crude oil [5], natural gas [6], and the most usable cuts such as naphtha, gasoline, and diesel, so that they are less 
harmful to man [7], especially when they contain sulfur and poisonous trace elements [8]. Thus, we carried out intensive research to separate hydrogen sulfide from our natural gas, and then decomposed it to clean hydrogen fuel and pure sulfur [9]-[11].

\section{EXPERIMENTAL ANALYSIS}

All chemicals were of Analar grade and were purchased from the Fluke and Merck Co. The experimental part of the study - the extraction of hydrogen sulfide from the gas of the Kirkuk wells - was performed using ethanol amine. The decomposition of this gas to hydrogen fuel and sulfur was achieved by separating it and sending it to two pilot plants, as shown in the Figs 1 and 2 [9], [10].

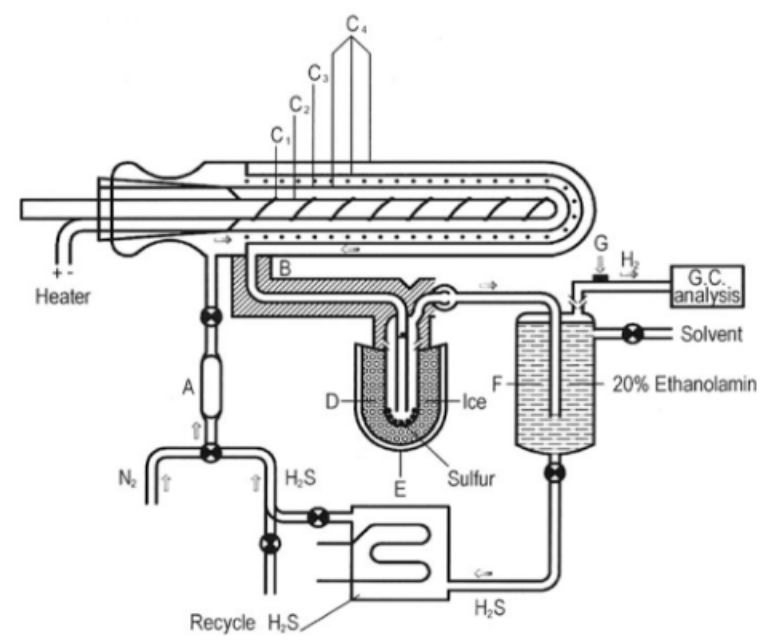

Figure 1: Pilot plant 1 for the decomposition of $\mathrm{H}_{2} \mathrm{~S}$. A: flowmenter; B: reactor (thermal diffusion column); $\mathrm{C} 1$ : heating wire; $\mathrm{C} 2$ : ceramic rod; $\mathrm{C}$ 3: catalysts; $\mathrm{C} 4$ : quartiz; D: trap for sulfur separation; E: sulfur condenser; F: 30-wt $\%$ DEA bath for $\mathrm{H}_{2} \mathrm{~S}$ separation: G: septum [11].

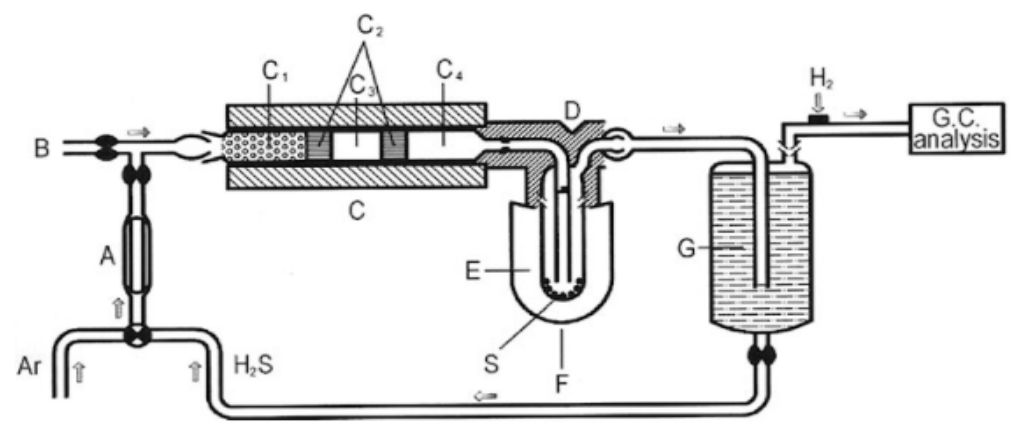

Figure 2: Pilot plant 2 for the decomposition of $\mathrm{H}_{2} \mathrm{~S}$. A: flowmeter; B: to vacuum line; $\mathrm{C}$ : tube furnace; $\mathrm{C} 1$ : pyrex balls; $\mathrm{C} 2$ : glass wool; $\mathrm{C} 3$ : catalysts; $\mathrm{C} 4$ : tube reactor; D: heating tape; E: trap for sulfur separation; F: sulfur condenser; G: 30-wt\% DEA bath for $\mathrm{H}_{2} \mathrm{~S}$ separation; $\mathrm{H}$ : gas sampling outlets septum [11]. 
The measurements of all physical and chemical properties have been made using modern instruments, as shown in Table 1.

Different postgraduate students have carried out systematic research work on the crude oils [5], gasoline cuts [12], diesel cuts [7], and trace metals [8] using American Standard Test Method (ASTM) and Institute of Petroleum (IP) methods for examining the physical and chemical properties of crude oils and their cuts.

\section{RESULTS AND DISCUSSION (CRUDE OIL AND ITS CUTS)}

The measurements of API gravity and sulfur content for three wells - Tawke, Taq-Taq, and Khurmala - are listed in Table 2.

Fig. 3 presents the distillation curves of the Tawke, Taq-Taq, and Khurmala crude oils.

A series of experiments were conducted to determine the properties of different crude oils as temperature versus accumulated volumes. Then, the carbon number of each distillate accumulated was determined using gas chromatography [5].

Tawke crude oil has a high percentage of C9, but Taq-Taq has C7, and Khurmala has C8, which represent the paraffinic hydrocarbon distributions, as shown in Fig. 4. Tawke crude oil has a high percentage of $\mathrm{C} 13$ and $\mathrm{C} 14$, but Taq-Taq has $\mathrm{C} 9$ and $\mathrm{C} 12$, and Khurmala has $\mathrm{C} 9, \mathrm{C} 13$, and $\mathrm{C} 14$, which represent paraffinic hydrocarbons.

Table 1: Apparatus and instruments employed.

\begin{tabular}{cl}
\hline 1 & Simple distillation apparatus ASTM D86, HAD 620 Herzog \\
\hline 2 & Fractional distillation apparatus ASTM D 285 \\
\hline 3 & Thermometer Quickfit B14, UK \\
\hline 4 & Gas chromatography instrument: Varian CP-3800 \\
\hline 6 & Pycnometer, (5 ml) volume, Germany \\
\hline 7 & Oxiscometer, Cannon-Fenske Routine, Eurostar Scientific LTD, PSL ASTM-IP 100 \\
\hline 8 & Water bath, Lab Tech, model LWB-122D, Korea \\
\hline 9 & Thermo-circulator, Lab Tech, Daihan Lab Tech Co, Model/ LCB-RO8, Korea \\
\hline 10 & Pensky-Martens closed cup, Flash Point Apparatus \\
\hline 11 & ACO-7 Cleveland open cup, Japan. Flash Point Apparatus \\
\hline 12 & Muffle Furness, Lab Tech, Korea \\
\hline 13 & Bellingham+ Stanley Ltd. Abbe 60/95 refractometer, UK \\
\hline 14 & Shatox Sx-100 M portable octane/cetane analyzer, Russia \\
\hline 15 & Oil product low-temperature characteristic meter OPLCM SX-800, Russia \\
\hline 16 & Titroline KF Trace Coulometric Karl Fischer Titrator, SCHOTT Instruments \\
\hline 17 & GmbH, Germany \\
\hline
\end{tabular}

Note: all of our crude oil and natural gas samples have been collected from different parts of the Kurdistan region. 
Table 2: The API gravity and sulfur content of three crude oils.

\begin{tabular}{cccc}
\hline Parameters & Tawke & Taq-Taq & Khurmala \\
\hline API gravity & 26.3 & 46.7 & 32.2 \\
Sulfur wt $\%$ & 2.82 & 0.65 & 2.48 \\
\hline
\end{tabular}

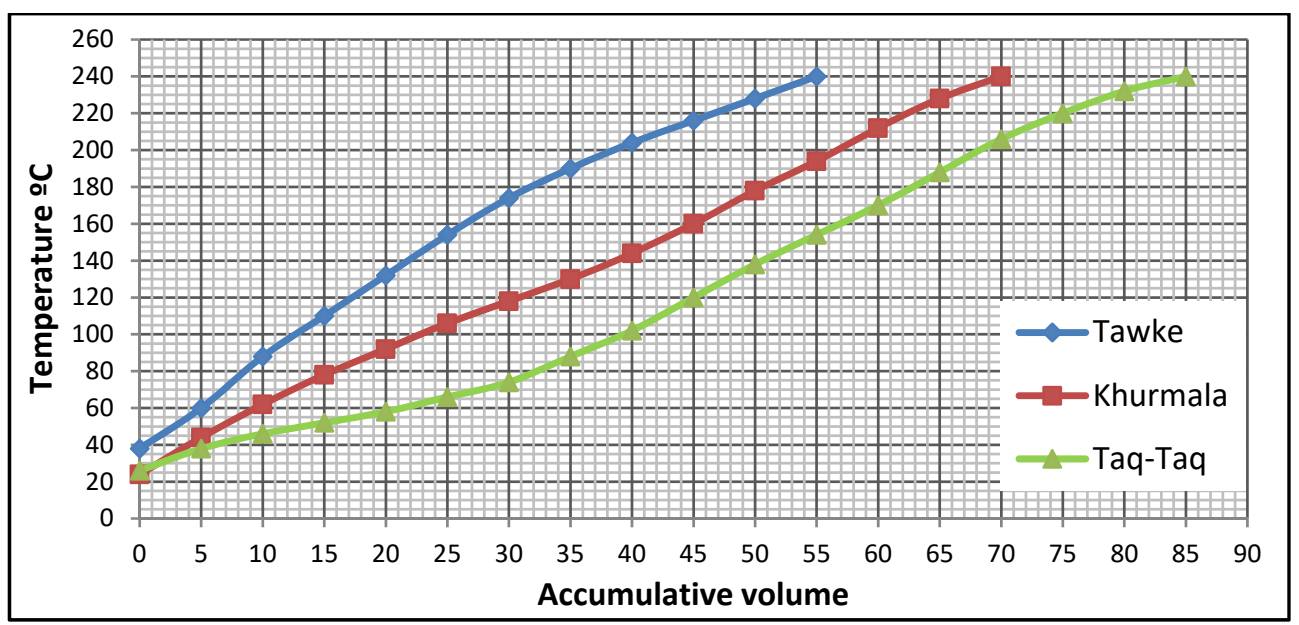

Figure 3: Distillation curve of Tawke, Khurmala, and Taq-Taq crude oils.

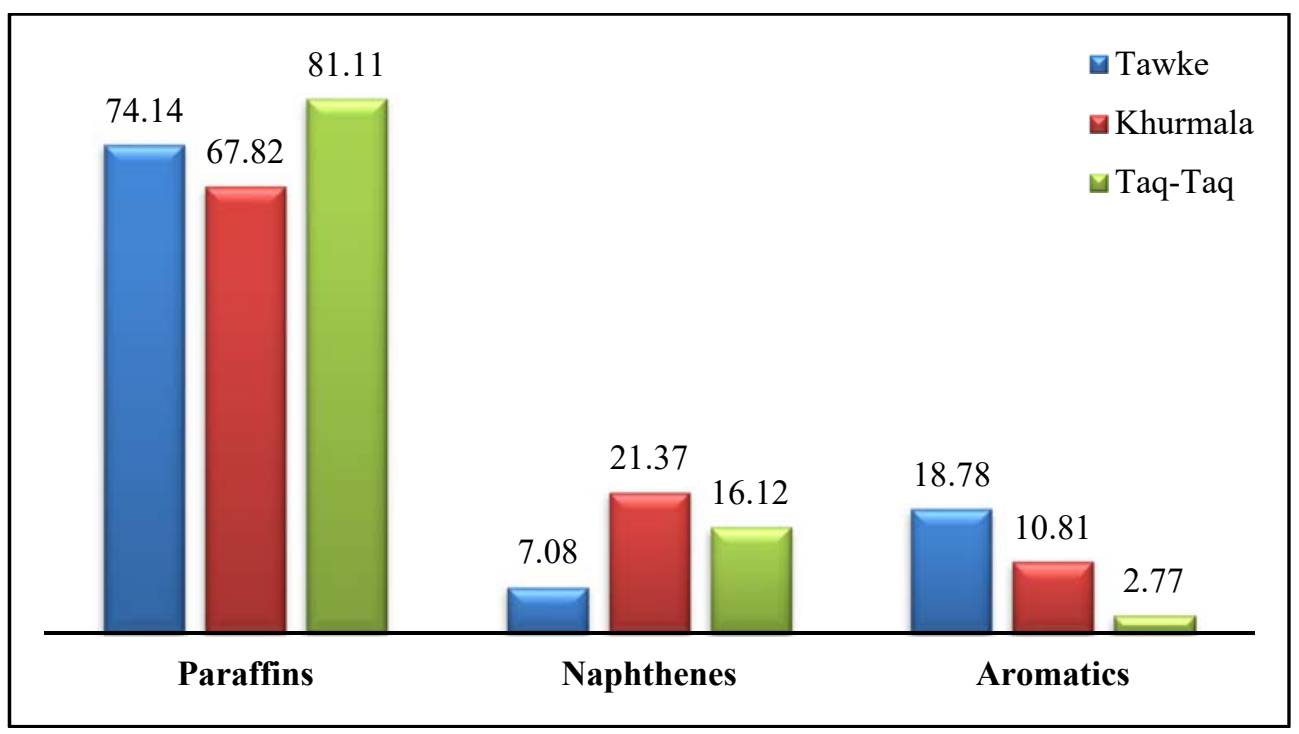

Figure 4: Paraffin, naphthene, and aromatic hydrocarbon distributions in fraction (1) at $100^{\circ} \mathrm{C}$ obtained via gas chromatography. 
Table 3 presents the weight percentage of the hydrocarbons, starting with carbon number four of fraction (1) (initial boiling point to $100^{\circ} \mathrm{C}$ ) and fraction (2) (from $100^{\circ} \mathrm{C}$ to $170^{\circ} \mathrm{C}$ ) by chromatography, as shown in Fig. 5, as an example of the analysis of one sample.

Gasoline straight cuts are collected from the crude oils to examine the increase of the octane number by oxygenated and organometallic octane additives, shown in Tables 4 and 5 respectively [12].

Table 3: Weight percentage of the carbon number for crude oil fractions.

\begin{tabular}{|c|c|c|c|c|c|c|}
\hline \multirow{2}{*}{$\begin{array}{l}\text { Carbon no. } \\
(\mathrm{wt} \%)\end{array}$} & \multicolumn{3}{|c|}{$\begin{array}{l}\text { Light naphthafrom initial boiling } \\
\text { point to } 100^{\circ} \mathrm{C}\end{array}$} & \multicolumn{3}{|c|}{$\begin{array}{l}\text { Heavy naphthafrom } 100^{\circ} \mathrm{C} \text { to } \\
\qquad 170^{\circ} \mathrm{C}\end{array}$} \\
\hline & Tawke & Taq-Taq & Khurmala & Tawke & Taq-Taq & Khurmala \\
\hline $\mathrm{C} 4$ & 0.00 & 0.34 & 0.42 & 0.00 & 0.00 & 0.00 \\
\hline $\mathrm{C} 5$ & 0.10 & 8.20 & 6.09 & 0.39 & 0.10 & 0.03 \\
\hline C6 & 1.00 & 22.35 & 16.59 & 1.06 & 0.23 & 0.17 \\
\hline $\mathrm{C} 7$ & 4.21 & 30.98 & 22.75 & 1.10 & 0.76 & 1.01 \\
\hline $\mathrm{C} 8$ & 16.76 & 26.69 & 26.79 & 2.24 & 15.29 & 9.07 \\
\hline C9 & 37.85 & 10.14 & 22.92 & 4.39 & 34.23 & 28.57 \\
\hline $\mathrm{C} 10$ & 16.61 & 0.84 & 2.35 & 3.32 & 14.60 & 9.35 \\
\hline $\mathrm{C} 11$ & 5.39 & 0.13 & 1.11 & 1.88 & 3.09 & 5.49 \\
\hline $\mathrm{C} 12$ & 11.05 & 0.20 & 0.48 & 11.94 & 12.00 & 8.36 \\
\hline $\mathrm{C} 13$ & 4.69 & 0.08 & 0.28 & 21.05 & 9.68 & 10.95 \\
\hline $\mathrm{C} 14$ & 1.62 & 0.01 & 0.03 & 21.28 & 5.70 & 10.56 \\
\hline $\mathrm{C} 15$ & 0.52 & 0.04 & 0.13 & 15.26 & 2.88 & 6.52 \\
\hline $\mathrm{C} 16$ & 0.20 & 0.02 & 0.06 & 6.72 & 1.44 & 4.43 \\
\hline Unknown 1 & 0.00 & 0.00 & 0.00 & 1.00 & 0.00 & 1.19 \\
\hline Unknown 2 & 0.00 & 0.00 & 0.00 & 2.16 & 0.00 & 2.68 \\
\hline Unknown 3 & 0.00 & 0.00 & 0.00 & 1.09 & 0.00 & 1.62 \\
\hline Unknown 4 & 0.00 & 0.00 & 0.00 & 3.36 & 0.00 & 0.00 \\
\hline Unknown 5 & 0.00 & 0.00 & 0.00 & 1.76 & 0.00 & 0.00 \\
\hline Total & 100 & 100 & 100 & 100 & 100 & 100 \\
\hline
\end{tabular}


86 Energy Production and Management in the 21st Century III

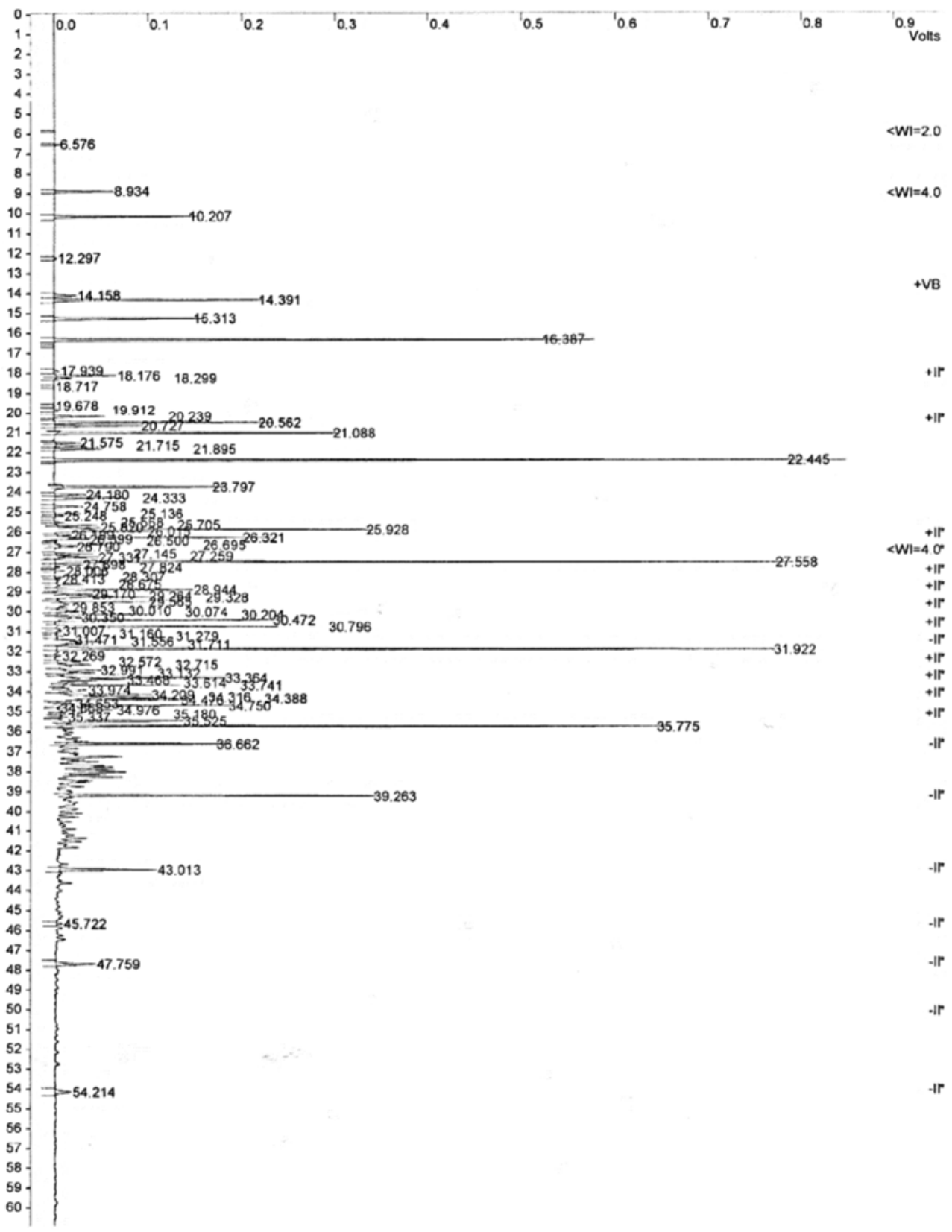

Figure 5: Gas chromatography chromatogram of Tawke crude oil with clay 3, fraction (1). 
Table 4: Changes in octane number $(\mathrm{ON})$ by oxygenated additives.

\begin{tabular}{cccc}
\hline No. & Sample & Range of change & $\Delta$ in ON \\
\hline 1 & TW4 gasoline & $72.9-83.4$ & 10.5 \\
2 & TW8 gasoline & $72.5-83.1$ & 10.6 \\
3 & Naphtha & $71.2-88.3$ & 17.1 \\
\hline
\end{tabular}

Table 5: Changes in octane number $(\mathrm{ON})$ by organometallic additives.

\begin{tabular}{cccc}
\hline No. & Sample & Range of change & $\Delta$ in ON \\
\hline 1 & TW4 gasoline & $73.2-81.3$ & 8.1 \\
2 & TW8 gasoline & $73.0-80.0$ & 7.0 \\
3 & Naphtha & $71.8-78.4$ & 6.6 \\
\hline
\end{tabular}

\subsection{Improvement of the crude oils with local clays}

In order to improve Tawke and Taq-Taq crude oils, which represent heavy and light crude oils, three types - clays (1), (2), (3) - of clays have been collected from different places in the Duhok governorate. The results of the X-ray fluorescence analysis for the three types of local clays are illustrated in Table 6, which shows the main differences in the percentages of silica oxide, alumina, and iron oxide. The $\mathrm{Si} /(\mathrm{Al}+\mathrm{Fe})$ ratio shows that clays (1) and (3) are similar to natural zeolite-type mordenite and erionite [5]-[7].

Fig. 6 shows that clays (1) and (3) have an ability to crack the heavy hydrocarbons in the Tawke crude oil with decreasing carbon numbers of hydrocarbon from C8 to C5 for clay (3), as well as for clay (1), but shifting to C9.

Table 6: Clay analysis.

\begin{tabular}{lccc}
\hline & Clay (1) & Clay (2) & Clay (3) \\
\hline $\mathrm{Al}_{2} \mathrm{O}_{3}$ & 7.71 & 6.72 & 6.11 \\
$\mathrm{SiO}_{2}$ & 42.05 & 33.37 & 39.42 \\
$\mathrm{Fe}_{2} \mathrm{O}_{3}$ & 5.56 & 11.40 & 6.03 \\
$\mathrm{CaO}$ & 17.54 & 5.30 & 5.40 \\
$\mathrm{MgO}$ & 4.23 & 15.73 & 14.80 \\
$\mathrm{Na}_{2} \mathrm{O}$ & 0.13 & 0.28 & 0.70 \\
$\mathrm{~K}_{2} \mathrm{O}$ & 0.96 & 0.43 & 0.95 \\
$\mathrm{SO}$ & 0.00 & 0.16 & 0.05 \\
$\mathrm{~L} . \mathrm{O} . \mathrm{I}$ & 21.86 & 26.23 & 24.97 \\
$\mathrm{Total}$ & 100.04 & 99.62 & 98.43 \\
$\mathrm{Si} /(\mathrm{Al}+\mathrm{Fe})$ & 3.17 & 1.84 & 3.25 \\
\hline
\end{tabular}


3.2 Evaluation and improvement of diesel cut from Tawke crude oil wells, Zakho

For evaluating the percentage of diesel in different crude oils, a preliminary distillation at atmospheric pressure was carried out according to ASTM D86. The percent of diesel was detected for each type of crude oil and then research was carried out to increase the quality and quantity of it by taking three types of local clays [7].

According to Fig. 7, the best reflex time for increasing the volume of diesel cuts for T-8 and T-16 crude oil using $6 \%$ wt of each clay was 6 hours.

Fig. 8 shows the ability of clays (1), (2), and (3) to crack the heavy hydrocarbon in $\mathrm{T}-8$ crude oil to a lighter hydrocarbon, as it is clear in the analysis of carbone distribution of diesel cut before and after.

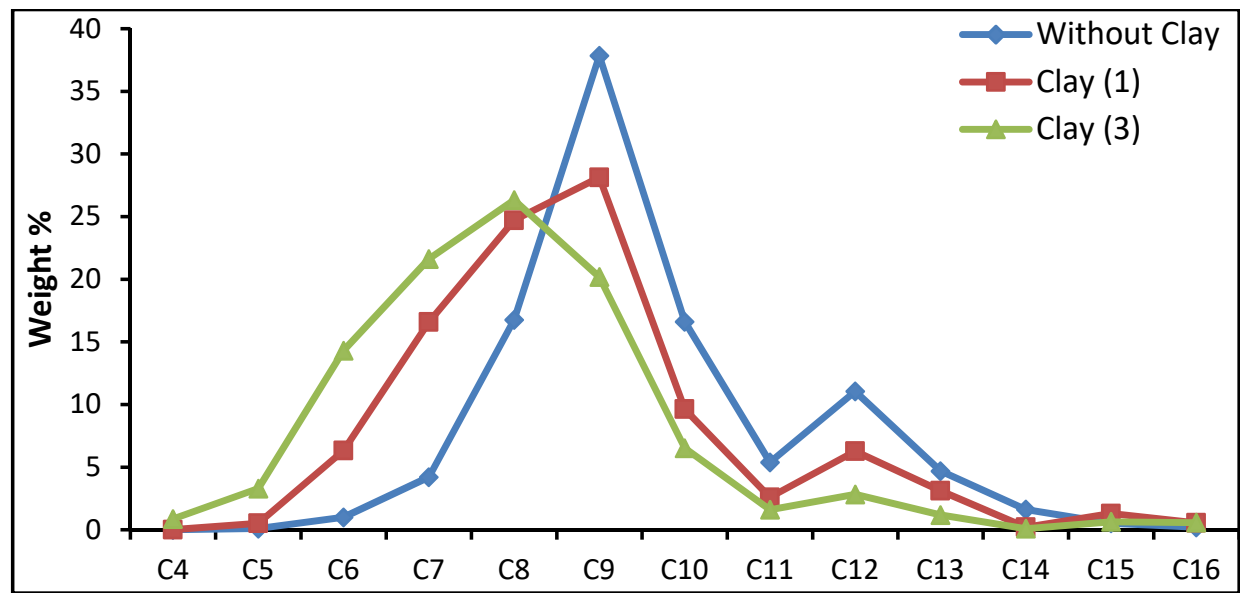

Figure 6: Carbon distribution of light fraction at $100^{\circ} \mathrm{C}$ before and after treatment of Tawke crude oil with clays (1) and (3).

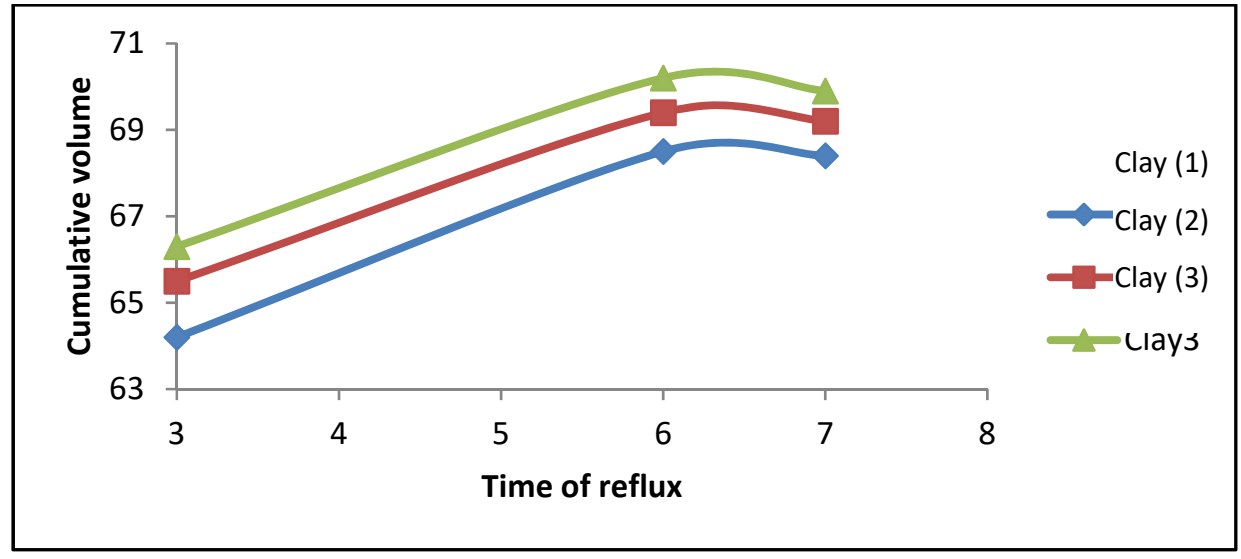

Figure 7: Effect of reflex time on the T-16 fractional distillation with $6 \%$ wt of clays (1), (2), and (3). 


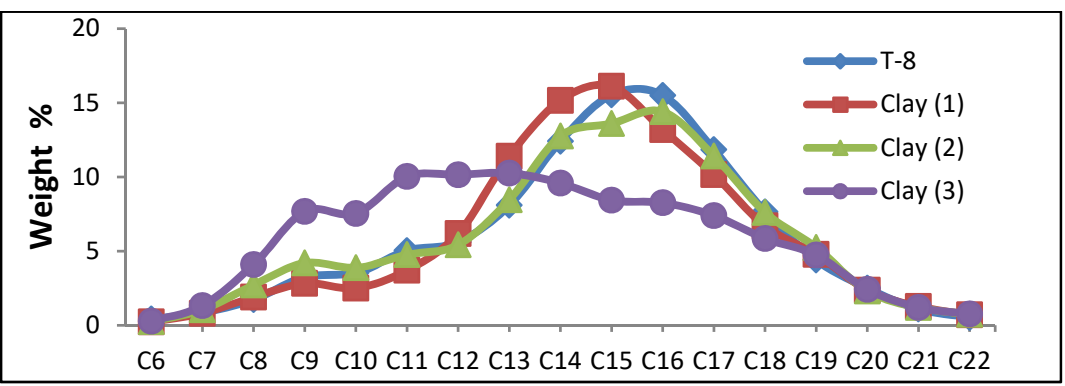

Figure 8: Carbon distribution of diesel fraction at $200-320^{\circ} \mathrm{C}$ before and after treatment T-8 crude oil with clays (1), (2), and (3).

\subsection{Correlation between trace metals in crude oil and type of hydrocarbon}

The total hydrocarbon in our sample of crude oil was $97.99 \% \mathrm{w}$, and its trace metals were $0.0129 \% \mathrm{w}$. The trace metals were determined via the carbon residue, and their ash analysis was carried out using inductive coupling plasma-optical emission spectroscopy. We also used atomic absorption spectroscopy.

The results show that this correlation depends on the characteristics of the crude oil well, including its depth, temperature, $\mathrm{pH}$, and the geological formation of the wells. Most of these trace elements have a tendency to form organometallic complexes on the bottom of the wells. We did not find any relation between these trace elements and the type of hydrocarbon in the crude oil.

\subsection{Separation and purification of natural gas}

The distillation fraction of the gas condensate of Khor Mor has been plotted in volume percent $(\& \mathrm{v} / \mathrm{v})$ as a function of distillation temperature, as shown in Fig. 9.

The gas chromatography shows the hydrocarbon-content carbon numbers C3-C13. Fig. 10 shows the percent of each carbon atom in the naphtha of Khor Mor.

The separation of $\mathrm{C} 1$ to $\mathrm{C} 5$ as a natural gas feeds two electrical power stations (Erbil and Sulamaniyh) the rest is condensate liquid ( $\mathrm{C} 5$ to $\mathrm{C} 12$ ) as light naphtha which is transferred to the refinery to improve the octane number of gasoline.

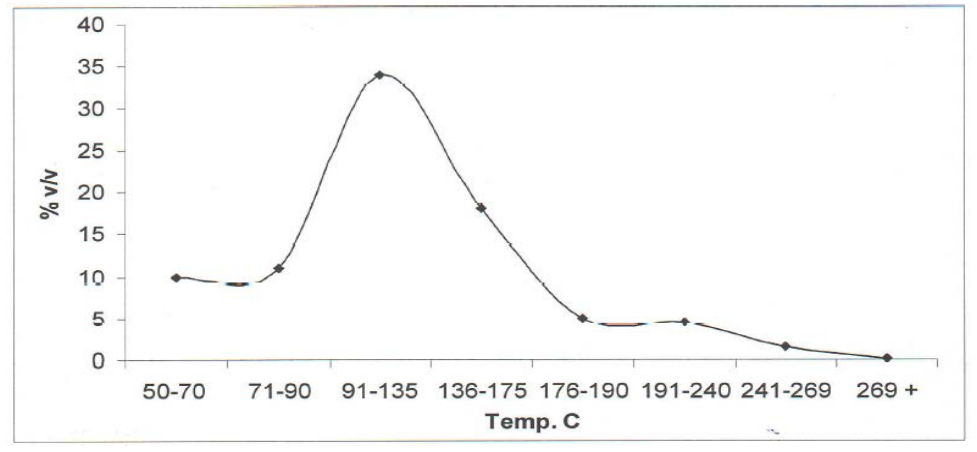

Figure 9: Fractional distillation curve. 


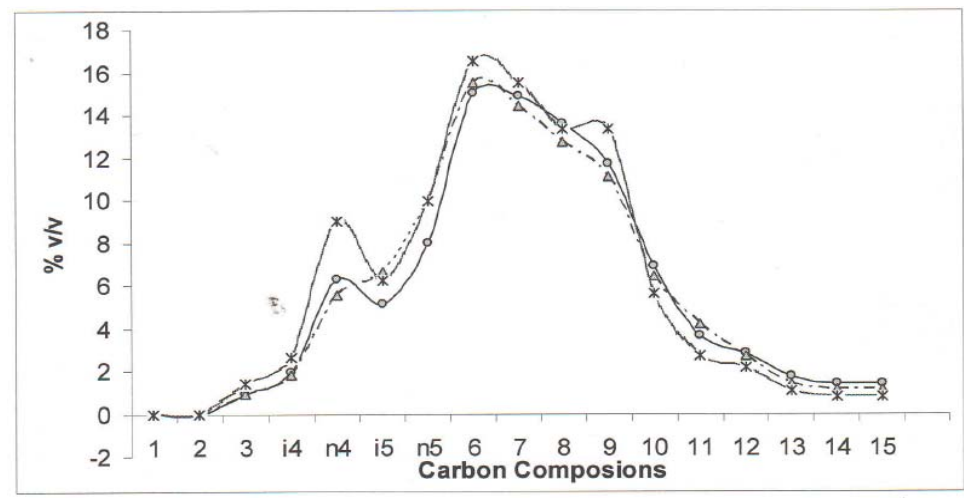

Figure 10: Analysis of the gas chromatography results.

\subsection{Separation and production of hydrogen sulfide from the Kirkuk wells}

Another group of postgraduate students studied the conversion of hydrogen sulfite after separating it from the natural gas of the Kirkuk wells using two different pilot plants 1 and 2, as shown in Figs 1 and 2, via thermal decomposition over a new catalyst at a temperature of approximately $400^{\circ} \mathrm{C}$.

These pilot plants will convert our Clause process plants in Kirkuk to produce hydrogen gas fuel and pure sulfur, and our calculation shows that we could produce 142 tons of hydrogen per day from the natural gas of the Kirkuk wells as it contains between $10 \%$ and $11 \% \mathrm{H}_{2} \mathrm{~S}$.

\section{CONCLUSIONS}

This paper is a general and basic part of our research on crude oils in Kurdistan-Iraq. Further details of this work can be found in our PhD and MSc theses [5]-[8], [12]. We aim to evaluate and improve the quality of our crude oil fuels and natural gases in light of the significant polluting effects they have on human health, and as an educational lesson for the new generation about the disadvantages of classical fuel. Our target is to substitute this classical fuel with clean hydrogen fuel and solar energy in the near future.

\section{REFERENCES}

[1] James, G.S., The Chemistry and Technology of Petroleum, 3rd ed., CRC Press: Wyoming, 2006.

[2] Simanzhenkov, V. \& Idem, R., Crude Oil Chemistry, CRC Press, 2003.

[3] Lur'e, M.A., Kurets, I.Z. \& Shmidt, F.K., The possible abiogenic origin of oil and gas chemistry and technology of fuels and oils. Chemistry and Technology of Fuels and Oils, 29(1-2), pp. 1-5, 2003.

[4] McQueen, D.R., The Chemistry of Oil Technology by Flood Geology, Institute For Creation Research: Santee, CA, 1986.

[5] Naman, S. \& Al-Ghalami, F.S., Assessment and Evaluation Study of Crude Oils in Kurdistan. PhD thesis, University of Zakho: Iraq, 2013.

[6] Naman, S., Natural condensed gas Khor-Mor official report Gara laboratory. www.sanaman.com, 2012. 
[7] Naman, S. \& Simo, S., Evaluation and Improvement of Diesel Cuts, Kurdistan-Iraq. MSc thesis, University of Zakho: Iraq, 2013.

[8] Naman, S., Othman, S. \& Hassein, H.M., Correlation Between Trace Metal.... MSc thesis, University of Zakho: Iraq, 2014.

[9] Naman, S., Kinetic study of thermal production of hydrogen from $\mathrm{H}_{2} \mathrm{~S}$. International Journal of Hydrogen Energy, 14(3), p. 173, 1989.

[10] Naman, S., Thermal production of hydrogen from $\mathrm{H}_{2} \mathrm{~S}$ using $\mathrm{V}_{\mathrm{x}} \mathrm{S}_{\mathrm{y}}$. International Journal of Hydrogen Energy, 15(1), pp. 1-5, 1990.

[11] Naman, S., Pilot plant for conversion of polluted $\mathrm{H}_{2} \mathrm{~S} / \mathrm{CO}_{2}$ in the oil field to produce clean fuel of hydrogen. Presented at Clean Energy 2000 Millennium Congress, Geneva, Switzerland, 2000.

[12] Naman, S. \& Amin, F., Evaluation and Improvement of Gasoline.... MSc thesis, University of Zakho: Iraq, 2011.

[13] Naman, S., Improvement of octane number using new nontoxic additives.... Majalat Al-Alom, 117, p. 18, 2001. 